\title{
Subtidal benthic recruitment in a sub-Arctic glacial fjord system: Temporal and spatial variability and potential drivers
}

\author{
Sarah B. Ørberg ${ }^{1,2,3}$ (D) Dorte Krause-Jensen ${ }^{2,3} \cdot$ Lorenz Meire $^{4,5} \cdot$ Mikael K. Sejr $^{2,3}$ \\ Received: 13 March 2018 / Revised: 12 August 2018 / Accepted: 25 August 2018 / Published online: 1 September 2018 \\ (c) The Author(s) 2018
}

\begin{abstract}
Increasing glacial discharge may influence future recruitment patterns and growth rates of marine benthos in glacial fjords as changes in surface-water temperature and salinity as well as an increase in ice-scouring events. We deployed settling plates at three spatial and temporal scales in a sub-Arctic glacial fjord system to quantify spatial and temporal variation in the recruitment rates and early growth of subtidal marine benthos, and to determine potential drivers of recruitment. We found significant spatial variation in recruitment of benthos (flora and fauna) at both the small $(20 \mathrm{~m})$ and large $(>30 \mathrm{~km})$ scale, indicating that both abiotic and biotic factors may be important. We observed that substrate modification by bushy macroalgae facilitated Mytilus spp. settlement, yet limited Semibalanus balanoides recruitment, underlining that timing in settlement of different species is important in structuring benthic communities. Spatial variation in physical parameters, such as temperature and salinity, likely affected growth and recruitment patterns of benthos (S. balanoides). Finally, we found large spatial and temporal variation in kelp recruitment varying from none to 5866 ind. $\mathrm{m}^{-2}$, with an annual production of more than $6000 \mathrm{~g} \mathrm{dw} \mathrm{m}^{-2}$ year $^{-1}$. This large growth potential of kelp suggests recruitment as a bottleneck in kelp population dynamics. Conclusively, variation in sub-Arctic benthic recruitment and growth patterns may respond to changes in temperature and salinity, yet further effort is needed to elucidate potential drivers of benthic recruitment in a fast changing Arctic environment.
\end{abstract}

Keywords Recruitment rates $\cdot$ Kelp $\cdot$ Barnacles $\cdot$ Greenland $\cdot$ Glacial discharge $\cdot$ Arctic benthos

\section{Introduction}

In polar regions, benthic communities in shallow areas contribute up to $83 \%$ of total productivity (Glud 2008) and play an important role in carbon cycling (Krause-Jensen

Electronic supplementary material The online version of this article (https://doi.org/10.1007/s00300-018-2390-6) contains supplementary material, which is available to authorized users.

Sarah B. Ørberg

sao@bios.au.dk

Dorte Krause-Jensen

dkj@bios.au.dk

Lorenz Meire

lome@natur.gl

Mikael K. Sejr

mse@bios.au.dk

1 Department of Bioscience, Aarhus University, 8000 Aarhus C, Denmark and Duarte 2016). In the Arctic, and especially in Greenland, glacial ice is discharged and lost at an increasing rate (Howat et al. 2007; Kjeldsen et al. 2015). The released icebergs increase the risk of ice scouring while melt water is likely to impact fjord circulations, surface-water temperature and salinity (Mortensen et al. 2011, 2014). These physical parameters are often suggested as important drivers of benthic recruitment in coastal areas (Wiencke et al. 2004; Fredersdorf et al. 2009; Woodson et al. 2012; Yakovis et al.

2 Department of Bioscience, Aarhus University, 8600 Silkeborg, Denmark

3 Arctic Research Centre, Aarhus University, 8000 Aarhus C, Denmark

4 Greenland Climate Research Centre, Greenland Institute of Natural Resources, 3900 Nuuk, Greenland

5 Department of Estuarine and Delta Systems, NIOZ Royal Netherlands Institute of Sea Research, Utrecht University, Yerseke, The Netherlands 
2013) which can influence benthic productivity. For example, in the sub-Arctic White Sea, the mean seasonal air temperatures were found to explain $20 \%$ of the annual variation in barnacle and ascidian recruitment (Yakovis et al. 2013). Temperature has also been found to influence the germination success of kelp zoospores (Fredersdorf et al. 2009). In addition, ice scouring can cause severe local damage to benthic communities and recolonization of newly scoured areas depends on the settlement rate of recruiting and migratory organisms (Gutt 2001).

Biotic interactions can also be key drivers of benthic recruitment (Bertness and Callaway 1994). For example, adult intertidal barnacles may attract barnacle larvae by chemical cues (Jarrett 1997). Nevertheless, the drivers of recruitment patterns are still poorly understood due to complex lifecycles, involving pelagic larval or spore stages before settling in the benthic environment. Due to the mosaic of multiple abiotic and biotic drivers possibly acting at different spatial and temporal scales, settlement and recruitment of marine benthos are often highly variable in time and space (Watson and Barnes 2004).
Few have studied settlement and recruitment patterns of subtidal benthos in Arctic fjords (Fetzer et al. 2002; Beuchel and Gulliksen 2008; Yakovis et al. 2013), and there are no studies from Greenland, which holds $12 \%$ of the world's coastline. This study is a first attempt to investigate potential drivers of subtidal macrobenthic settlement and recruitment across a temporal and spatial scale in Greenland. We deployed settling plates, a standard tool in quantifying recruitment and early growth (Khalaman et al. 2016), at varying distances from a glacial output in a sub-Arctic fjord system in south west Greenland, while monitoring key physical parameters such as temperature, light and salinity.

\section{Materials and methods}

The study was conducted in the sub-Arctic Godthåbsfjord system, south west Greenland $\left(64^{\circ} \mathrm{N}, 51^{\circ} \mathrm{W}\right)$ (Fig. 1), covering an area of $2013 \mathrm{~km}^{2}$ where the inner part of the main fjord is in contact with three tidal outlet glaciers (Mortensen et al. 2011). The system is influenced by strong tides
Fig. 1 Map of the Godthåbsfjord system, south west Greenland $\left(64^{\circ} \mathrm{N}, 51^{\circ} \mathrm{W}\right)$, outlining the position of stations where settling plates were deployed 2009-2010 (Q1, Q2, Q3) and 2016-2017 (K, F, G), respectively

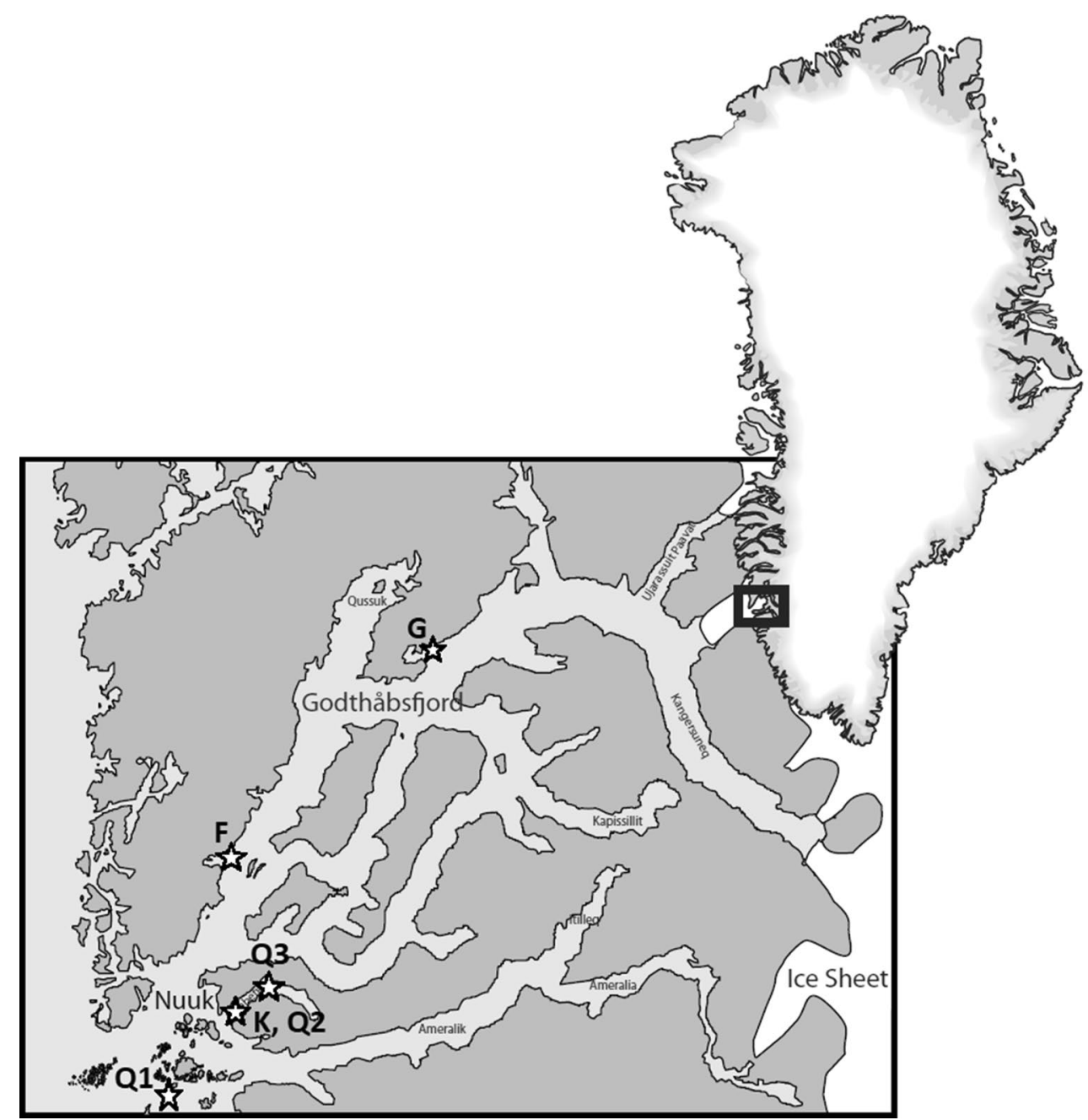


with a neap spring tidal range between 0.81 and $5.36 \mathrm{~m}$ (Mortensen et al. 2011) and during spring and summer, it receives large amounts of freshwater from melting glaciers and runoff from snow-covered areas (Van As et al. 2014). In winter, the innermost part of the main fjord and some of the fjord branches, e.g. Kobbefjord (K), are covered with sea ice. This results in a system characterized by large seasonal variation in key physical parameters such as light, temperature and salinity. From August 2009 to August 2010, 18 settling plates $\left(11 \times 11 \mathrm{~cm}=0.0121 \mathrm{~m}^{2}\right)$ were deployed at three stations in the Godthåbsfjord system $(\mathrm{Q} 1, \mathrm{Q} 2, \mathrm{Q} 3)$ (Fig. 1), with 6 plates per station. In April 2016, 80 settling plates $\left(12 \times 16 \mathrm{~cm}=0.0192 \mathrm{~m}^{2}\right)$ were deployed across 7 stations in the Godthåbsfjord system $\left(\mathrm{G}, \mathrm{F}, \mathrm{K}_{1 \mathrm{a}}, \mathrm{K}_{1 \mathrm{~b}}, \mathrm{~K}_{1 \mathrm{c}}\right.$, $\mathrm{K}_{2}, \mathrm{~K}_{3}$ ) (Fig. 1). Half of the plates in each station were harvested after 4 months (Apr 2016-Aug 2016) and replaced with new plates (deployed then from Aug 2016-Apr 2017) while the remaining stayed at the location for a full year (Apr 2016-Apr 2017). Per station and per time period, we had 4 replicates. The deployment covered three spatial scales: three fjord branches (stations G, F, K) (> $30 \mathrm{~km}$ apart), three sites within a single fjord (Kobbefjord; $\mathrm{K}_{1}, \mathrm{~K}_{2}$, $\left.\mathrm{K}_{3}\right)(2 \mathrm{~km}$ apart) and three stations within a site in Kobbefjord ( $\left.\mathrm{K}_{1 \mathrm{a}}, \mathrm{K}_{1 \mathrm{~b}}, \mathrm{~K}_{1 \mathrm{c}}\right)(20 \mathrm{~m}$ apart) (Fig. 1). In 2009, we used PVC settling plates (transparent), treated with coarse sandpaper (Grit 24) to create a rough surface. In 2016, we used polyethylene cutting boards (white) also treated with coarse sandpaper. The plates were attached with cable ties to a larger PVC baseplate (grey) $(30 \times 40 \mathrm{~cm}$ in 2009) $(40 \times 60 \mathrm{~cm}$ in 2016). All the plates were positioned horizontally in the water column. Deployment Q1, Q2 and Q3 were located $10 \mathrm{~m}$ below mean tide, close to the bottom, weighed down by $6 \mathrm{~kg}$ weights and held upright by a submerged buoy. $\mathrm{K}_{1}, \mathrm{~K}_{2}, \mathrm{~K}_{3}$ were deployed similarly but at a shallower depth, $5 \mathrm{~m}$ below mean tide. $\mathrm{F}$ and $\mathrm{G}$ were deployed $5 \mathrm{~m}$ below mean tide and held in place by a steel wire attached to a steep cliff, weighed down by $2 \mathrm{~kg}$ weight as the steep bottom topography did not allow a similar deployments in these fjord sections.

To quantify the physical conditions, HOBO light + temperature loggers (30 min logging rate) were attached directly onto deployments $\mathrm{Q}_{2}, \mathrm{~K}_{2}, \mathrm{~K}_{3}, \mathrm{G}$ and $\mathrm{F}$, and additional HOBO temperature loggers were attached to deployment $\mathrm{K}_{1 \mathrm{a}}, \mathrm{K}_{1 \mathrm{~b}}, \mathrm{~K}_{1 \mathrm{c}}$. We obtained surface salinity measurements (10 min logging rate) from moorings at $5 \mathrm{~m}$ depth, which were positioned close to the deployment structures for 1 year (Jan '16-Jan '17) and expected to reflect minimum/maximum values similar to the 1 year deployment period (April '16-April '17). We calculated day degrees for each station by summing up the mean daily temperatures over a year (April '16-April '17). To quantify the presence and percent cover of macrobenthos, the seabed was filmed with an underwater camera in April 2017 close to each deployment $(0-30 \mathrm{~m})$.

All algal specimens were counted, measured by length, freeze-dried (Christ Alpha 1-2 LD plus) and weighed. For a fraction of the samples that were not freeze-dried, dry weight was estimated based on dw/ww ratios established from the freeze-dried samples. Subsamples for identification of species under microscope were preserved in a solvent of $2 / 3$ corn syrup (Karo light corn syrup), 1/3 water and a few drops of Atamon (own recipe). Mussels and barnacles were identified to species, counted, measured by maximum dimension and freeze-dried. Other invertebrates were counted, but their occurrence was limited. At the underside of the baseplates, we counted and measured barnacles by maximum dimension (i.e. carapace diameter); at high densities, only $1 / 2$ or $1 / 4$ of the plate surface was processed.

To compare the variation in algal biomass per time period between stations (F, G, K) within each of the spatial scales (site, fjord, fjord system), we applied a one-way ANOVA or Kruskal-Wallis test. In the fjord-scale analysis, we compared stations $\mathrm{K}_{2}, \mathrm{~K}_{3}$ and $\mathrm{K}_{1 \mathrm{c}}$, the latter chosen randomly among three replicate $\mathrm{K}_{1}$ stations $\left(\mathrm{K}_{1 \mathrm{a}}, \mathrm{K}_{1 \mathrm{~b}}, \mathrm{~K}_{1 \mathrm{c}}\right)$. In the fjord system scale analysis, we compared station $\mathrm{G}, \mathrm{F}$ and $\mathrm{K}_{3}$, the latter chosen randomly from the five Kobbefjord stations $\left(\mathrm{K}_{1 \mathrm{a}}, \mathrm{K}_{1 \mathrm{~b}}\right.$, $\mathrm{K}_{1 \mathrm{c}}, \mathrm{K}_{2}, \mathrm{~K}_{3}$ ). To assess the relation between barnacle size and day degrees, we applied a linear regression analysis. We used the statistical software R (R Core Team 2017) for analysis and processing of the data.

\section{Results and discussion}

\section{Temperature, salinity and light}

We found a clear gradient in physical parameters between stations. Salinity and temperature were lowest at the inner part of Godthåbsfjord (G), closest to the glaciers discharging large amounts of freshwater and ice during the melting season, and highest in Kobbefjord (K), furthest away from the glaciers (Fig. 2). At the inner part of Godthåbsfjord (G), the temperature ranged between 0 and $8^{\circ}$ in summer and from -2 to $2^{\circ} \mathrm{C}$ in winter, displaying the most variable winter temperature compared to all the other stations (Fig. 2). Day degrees, mean daily temperatures accumulated over a year, were highest in Kobbefjord $(\mathrm{K})$ and lowest at the innermost station in Godthåbsfjord (G). Over a year, minimum mean daily salinities varied considerably between stations (Table 1). The lowest mean daily salinity was recorded at the innermost station in Godthåbsfjord $(\mathrm{G})$ (12.4 psu) and the highest (28.3 psu) at the outermost stations [Kobbefjord (K)]. Inconsistency in light logging during 2016-2017 precludes clear patterns in light intensity, but light intensity 

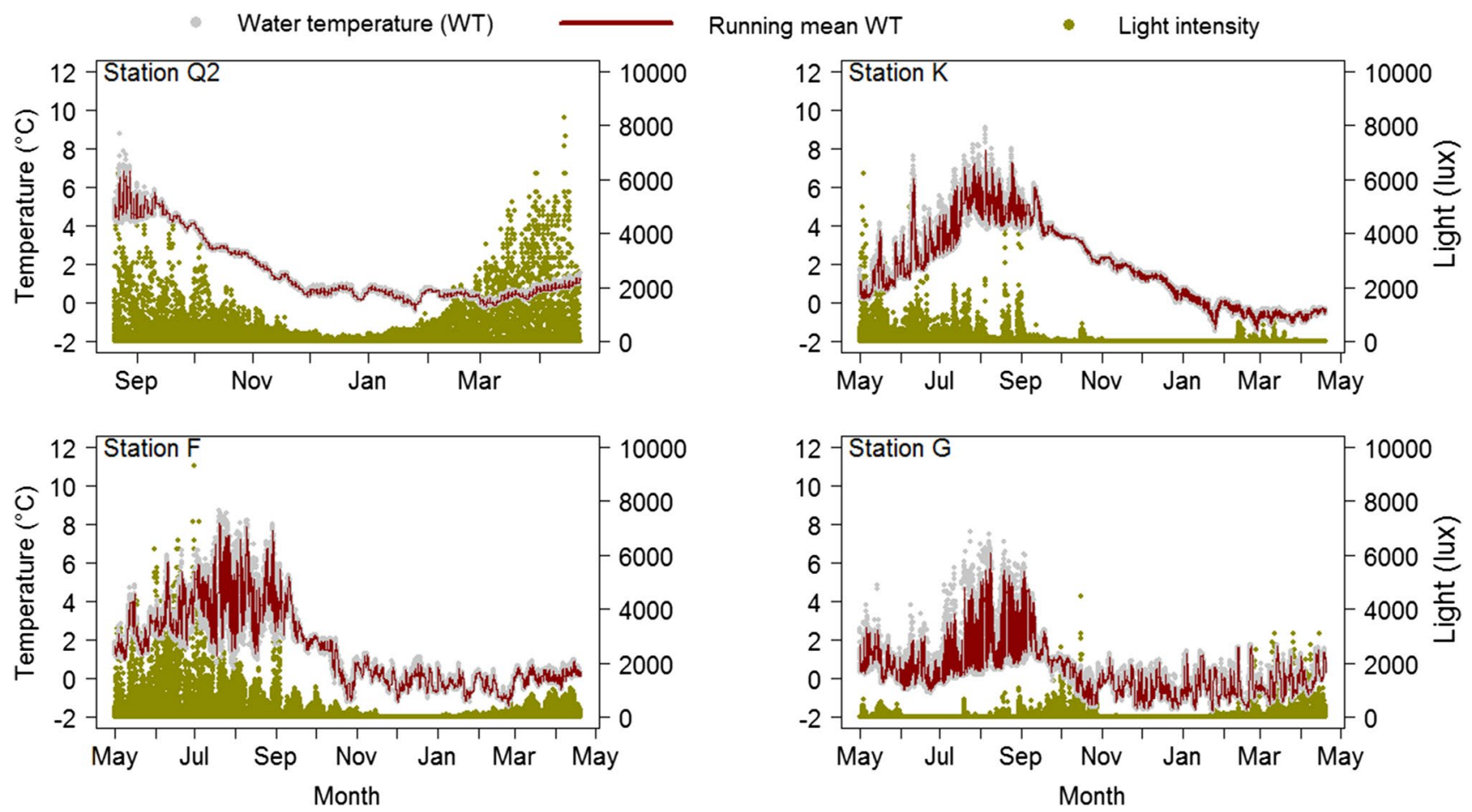

Fig. 2 Water temperature (running mean over 10 observations at a time) and light intensity from station Q2 at $10 \mathrm{~m}$ depth 2009-2010 and stations $\mathrm{K}, \mathrm{F}$ and $\mathrm{G}$ at $5 \mathrm{~m}$ depth in the Godthåbsfjord system 2016-2017, south west Greenland. In 2016-2017, the light measure-

ments display some inconsistency with sudden drops in the measurements that may be due water movements turning the logger around occasionally
Table 1 Position of stations, deployment period and annual minimum/maximum salinity at each of the stations $\mathrm{G}, \mathrm{F}$ and $\mathrm{K}$

\begin{tabular}{lllll}
\hline Station & Position & Deployment period & $\begin{array}{l}\text { Salinity (psu), } \\
\text { max }\end{array}$ & $\begin{array}{l}\text { Salinity } \\
(\mathrm{psu}), \\
\text { min }\end{array}$ \\
\hline $\mathrm{Q}_{1}$ & $64^{\circ} 02.086 \mathrm{~N} ; 51^{\circ} 45.684 \mathrm{~W}$ & Aug-Aug $^{\mathrm{a}}$ & - & - \\
$\mathrm{Q}_{2}$ & $64^{\circ} 08.111 \mathrm{~N} ; 51^{\circ} 35.566 \mathrm{~W}$ & Aug-Aug $^{\mathrm{a}}$ & - & - \\
$\mathrm{Q}_{3}$ & $64^{\circ} 10.395 \mathrm{~N} ; 51^{\circ} 29.458 \mathrm{~W}$ & Aug-Aug $^{\mathrm{a}}$ & - & - \\
$\mathrm{G}$ & $64^{\circ} 39.702 \mathrm{~N} ; 50^{\circ} 57.105 \mathrm{~W}$ & April-April $^{\mathrm{b}}$ & 33.1 & 12.4 \\
$\mathrm{~F}$ & $64^{\circ} 21.389 \mathrm{~N} ; 51^{\circ} 40.510 \mathrm{~W}$ & April-April $^{\mathrm{b}}$ & 33.3 & \\
$\mathrm{~K}$ & $\mathrm{~K}_{1}-\mathrm{K}_{3}$ & April-April $^{\mathrm{b}}$ & 33.1 & \\
$\mathrm{~K}_{1}$ & $64^{\circ} 08.975 \mathrm{~N} ; 51^{\circ} 37.583 \mathrm{~W}$ & April-April $^{\mathrm{b}}$ & & \\
$\mathrm{K}_{2}$ & $64^{\circ} 08.551 \mathrm{~N} ; 51^{\circ} 35.456 \mathrm{~W}$ & April-April $^{\mathrm{b}}$ & & \\
$\mathrm{K}_{3}$ & $64^{\circ} 07.739 \mathrm{~N} ; 51^{\circ} 37.593 \mathrm{~W}$ & April-April $^{\mathrm{b}}$ & & \\
$\mathrm{K}_{1 \mathrm{a}}$ & Same as K1 & April-April $^{\mathrm{b}}$ & \\
$\mathrm{K}_{\mathrm{lb}}$ & Same as K1 & April-April $^{\mathrm{b}}$ & \\
$\mathrm{K}_{\mathrm{lc}}$ & Same as K1 & April-April $^{\mathrm{b}}$ & & \\
\hline
\end{tabular}

Salinity measurements were obtained over a full year cycle (January 1, 2016-January 1, 2017) which is expected to reflect minimum/maximum values similar to the 1-year deployment period (April '16-April '17)

a2009-2010

b2016-2017 seemed to be lowest at the inner part of Godthåbsfjord $(\mathrm{G})$ and highest in the outer part (F) (Fig. 2). This trend has also been observed in other studies, suggesting that the high input of silt concomitant with the meltwater strongly impacts the light climate in the fjord system (Murray et al. 2015; Meire et al. 2017). 


\section{Macroalgal recruitment}

We found a high density and biomass of settled kelp, Saccharina sp. and Alaria esculenta, at station Q1, while Q2 and Q3 displayed low or no settling of benthos (Online Resource 1). These plates were mainly covered by a thin biofilm. In the Godthåbsfjord, fruiting sori of kelp have been observed in August (Krause-Jensen et al. 2012), suggesting that spores may have settled rather quickly after deployment of plates in August at Q1, and we may have missed the window for settling at the other stations. Saccharina sp. was mostly identified as Saccharina longicruris. Figure 4 illustrates the vertical distribution of blade biomass and density of each kelp species along the upper 5-10 m water column. The highest blade biomass for Saccharina sp. was found on the rope at 6-7 $\mathrm{m}$ depth $\left(6800 \mathrm{~g} \mathrm{dw} \mathrm{m}^{-2}\right.$ year $\left.^{-1}\right)$; the highest density was on the rope at 5-6 m depth (5866 ind. $\mathrm{m}^{-2}$ ) (Online Resource 2), and their product, biomass per individual, peaked at $11.6 \mathrm{~g}_{\text {ind. }}{ }^{-1}$ year $^{-1}$ on the buoy at $5 \mathrm{~m}$ depth. On the settling plates, blade biomass and density of both kelp species were similar (Saccharina sp.: 977 ind. $\mathrm{m}^{-2}, 520 \mathrm{~g} \mathrm{dw} \mathrm{m}^{-2}$ year $^{-1}$; A. esculenta: 647 ind. $\mathrm{m}^{-2}, 440 \mathrm{~g}$ $\mathrm{dw} \mathrm{m}^{-2}$ year $^{-1}$ ), but low compared to the rope and buoy. The decline in biomass with depth was likely caused by shading and density-dependent mechanisms (Schiel and Foster 2006). Moreover, the different substrate materials may have affected the pattern. While other studies report annual growth of mature kelps in Greenland at up to $175 \mathrm{~g}$ $\mathrm{dw}$ year ${ }^{-1}$ and $0.6-2.2 \mathrm{~m}$ year $^{-1}$, with values from the Godthåbsfjord being $130-175 \mathrm{~g} \mathrm{dw}$ year $^{-1}$ and $1.8-2 \mathrm{~m}$ year $^{-1}$ (Krause-Jensen et al. 2012), the current findings document that Greenland kelps also have a marked potential for colonization and fast early growth.

Contrary to the earlier observations in 2009-2010, no kelps were found on the settling plates, rope or buoy deployed in 2016-2017, despite kelps being present near the plates. Video-surveying of the surroundings of all deployments in April 2017 (Online Resource 3) showed the presence of kelp but the percent coverage varied greatly, suggesting that also on natural surfaces kelp recruitment may show large variation in time and space. Integrated with the earlier deployments, this shows that kelp recruitment varies greatly from zero settling to 5866 ind. $\mathrm{m}^{-2}$, with an annual production of more than $6000 \mathrm{~g} \mathrm{dw} \mathrm{m}^{-2}$ year $^{-1}$. This demonstrates a large growth potential once kelp spores settle, yet recruitment may be a bottleneck in kelp population dynamics. The change in deployment depth and plate material between deployments in 2009-2010 and 2016-2017 was not expected to influence settling of kelp, as settling and high growth also occurred on the buoy at $5 \mathrm{~m}$ depth in 2009-2010. Moreover, the plates deployed in 2016-2017 (Online Resource 4) displayed similar biofilm growth as the plates deployed in 2009-2010 at Q2 and Q3 (Online Resource 1). Generally, the recruitment in 2016-2017 was dominated by bushy algae with mean biomasses up to $300 \mathrm{~g} \mathrm{~m}^{-2}$ (Fig. 3), primarily of the species Desmarestia aculeata in Kobbefjord (K). Other settled algal species were Dictyosiphon foeniculaceus and Ectocarpus sp, the latter dominating in the inner Godthåbsfjord $(\mathrm{G})$.

Settling occurred mainly in the period April-Aug, as we found very little or no settling on plates deployed Aug-Apr (Fig. 3). However, in the inner Godthåbsfjord (G), we found considerable settling by Ectocarpus sp. in Aug-April, and the kelp colonization recorded in 2009-2010 settled in August or later. The algal biomasses developed on the plates from April to August 2017 differed significantly between stations at the site scale, and differences were border-significant (ANOVA, $\mathrm{F}_{(2,9)}=4.22, p=0.051$ ) between stations at the fjord system scale (Table 2). In the period April'16-April ' 17 , algal biomass only varied significantly between stations at the fjord system scale (Table 2).

Conclusively, the settlement and growth of macroalgae varied on both the small $(20 \mathrm{~m})$ and the large $(>30 \mathrm{~km})$ spatial scale, suggesting that both abiotic and biotic factors may be key drivers of recruitment and early growth. Key physical conditions showed very low variation at the small scale, where biological factors, such as the proximity of the bushy brown algae, D. aculeata, to plates, may have caused the small-scale variation we found. However, abiotic factors unaccounted for, such as flow velocity and local bathymetry, could also be at play. Within the large spatial scale, we found high variation in temperature and salinity (Table 1, Fig. 2) and significant variation in recruitment rates (Table 2), suggesting that temperature and salinity may act as important drivers of recruitment within large spatial scales.

\section{Mussel and barnacle recruitment}

We observed high densities of juvenile mussels Mytilus spp. ( $<3 \mathrm{~mm}$ ) entangled in D. aculeata in 2016-2017, but only on plates deployed for the full year, suggesting that settling of Mytilus spp. occurred between August and April likely associated with the presence of $D$. aculeata. This corresponds to the spawning of Mytilus trossulus in July, observed in a north west Greenlandic fjord (Thyrring et al. 2017), as settlement onto bushy structures is expected 1-2 months after spawning, i.e. Aug/Sep, before moving into the adult patches (Lane et al. 1985). In addition, Gammarus sp. and Caprella septentrionalis were often found entangled in $D$. aculeata, as also documented in Kongsfjorden, Svalbard (Lippert et al. 2001). However, we also observed Gammarus sp. and C. septentrionalis on settling plates at station $\mathrm{F}$ and $\mathrm{G}$, where D. aculeata was limited or absent.

We found that the density of Semibalanus balanoides colonizing the underside of baseplates was quite variable between stations (Q1, Q2 and Q3) in 2010 and the highest 
April '16 - April '17 $\square$ April '16 - Aug '16 $\square$ Aug '16 - April '17

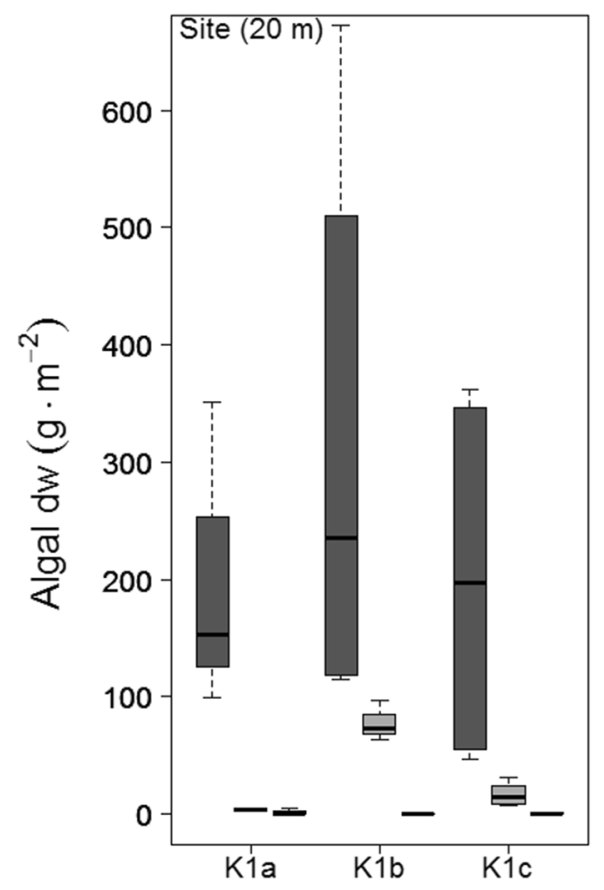

Fig. 3 Algal dry weight (dw) biomass found on settling plates at three spatial scales (site, fjord, fjord system) over three time periods (April-April, April-Aug, Aug-April) within 2016-2017 in the God-

Table 2 One-way ANOVA testing the variation in algal biomass (WW) between stations within a site, fjord or fjord system in the two time periods (April '16-Aug '16 and April '16-April '17) ( $n=4$ at each station per time period). For asteriks symbol marked with a, Kruskal-Wallis test was applied

\begin{tabular}{lcl}
\hline Spatial scale & $\mathrm{F}_{(2,9)} /$ Chisq & $p$ \\
\hline Site $(20 \mathrm{~m})$ & & \\
April-Aug & 31.66 & $0.000158^{* * *}$ \\
April-April & 0.32 & 0.609 \\
Fjord $(2 \mathrm{~km})$ & & \\
April-Aug & 4.22 & 0.051 \\
April-April & 1.93 & 0.201 \\
Fjord system $(>30 \mathrm{~km})$ & & \\
April-Aug & 7.90 & $0.01923^{*}$ \\
April-April & 6.34 & $0.0191^{*}$ \\
\hline
\end{tabular}

density was observed at Q1 (5233 ind..$^{-1} \mathrm{~m}^{-2}$ ) (Fig. 4a). In August 2017, the density and size of $S$. balanoides was low on the plates compared to the underside of the baseplate also displaying high variation between sites (Fig. 4b, c). On all 120 plates deployed in 2016-2017, we found 8 individuals of $S$. balanoides, and none of them were recorded in the period Aug'16-Apr '17. This pattern could be related to the fast colonization and growth by $D$. aculeata on plates thåbsfjord system, south west Greenland $(n=4)$. Boxplots present the minimum, the lower quartile, the median, the upper quartile and the maximum

posing an overall negative affect on $S$. balanoides recruitment (Jenkins et al. 1999) or a preference for the material of the baseplates or their position in the water column. Other studies have also reported that recruitment of benthic fauna, including barnacles, is higher on the underside of plates, suggesting that algae are competitively superior on the top side (Khalaman et al. 2016). Hence, modification of the settling surface appears important as indicated by the potential negative effect of algae on $S$. balanoides and positive effect of algae on Mytilus spp., indicating that timing of settling between different species is decisive in structuring benthic communities.

In 2017 , the highest density of $S$. balanoides colonizing undersides of baseplates was found in Kobbefjord (K) (183 ind. ${ }^{-1} \mathrm{~m}^{-2}$ ) (Fig. 4b), and we already observed colonizers $(<10 \mathrm{~mm}) 4$ months after deployment. This corresponds to earlier documentation of $S$. balanoides settling occurring in the Arctic mid-summer (FeylingHanssen 1953). Both density and growth rate of S. balanoides seemed higher in Kobbefjord (K) than at stations further into the Godthåbsfjord system (F and G) (Fig. 4b, c), yet the low number of replicate baseplates precluded testing for statistical differences. The spatial pattern in $S$. balanoides recruitment was related to temperature, as day degrees were lower in both stations further into the 

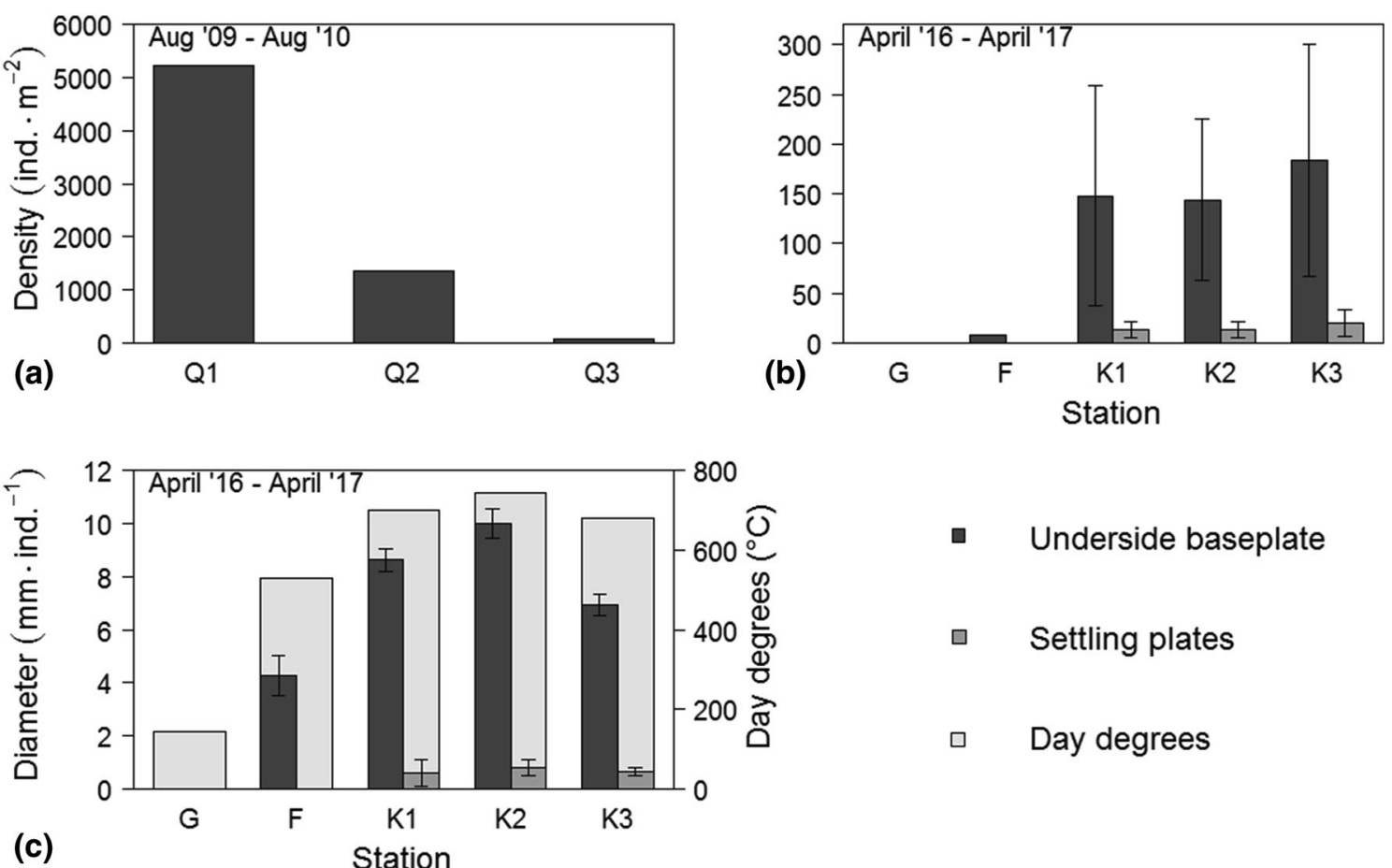

- Underside baseplate

$\square \quad$ Settling plates

$\square \quad$ Day degrees

Fig. 4 Semibalanus balanoides after 1 year of colonization on settling plates and/or the underside of baseplates in the Godthåbsfjord system, south west Greenland. a Density at the underside of baseplates after deployment August 2009-August $2010(n=1)$, b density and c size distribution and day degrees on settling plates and the underside of baseplates after deployment April' 16-April '17 [baseplates: G and F, $(n=1)$ and $\mathrm{K},(n=2)$, settling plates $\mathrm{G}$ and $\mathrm{F},(n=4)$ and $\mathrm{K},(n=8)]$. Error bars are SE

drivers of recruitment patterns and growth of Arctic benthic communities, as environmental factors, including the risk of ice scouring, are changing fast.

Acknowledgements We thank the Otto Bruuns foundation, Oticon foundation and SAFT (Selskabet for Arktisk Forskning og Teknologi) for supporting the fieldwork in April 2017 and we thank the Carlsberg Foundation (grant number CF15-0639) for logistic support to the fieldwork in August 2016. We thank the Greenlandic Institute of Natural Resources (GINR), Nuuk, Greenland, and their staff for providing excellent working conditions. Moreover, we wish to thank Martina Pösnecker, Núria Marbà, Scott Bennett and Wieter Boone for help with fieldwork sampling.

Funding This study was funded by Otto Bruuns foundation, Oticon foundation, and SAFT (Selskabet for Arktisk Forskning og Teknologi). Carlsberg Foundation (Grant Number CF15-0639) provided logistic support to the fieldwork in August 2016.

\section{Compliance with ethical standards}

Conflict of interest All authors declared that they have no conflict of interest.

Ethical approval All applicable international, national, and/or institutional guidelines for the care and use of animals were followed. patterns and growth rates for marine benthos and ultimately affect benthic community structure. However, we stress that further effort is needed in studying potential 
Open Access This article is distributed under the terms of the Creative Commons Attribution 4.0 International License (http://creativeco mmons.org/licenses/by/4.0/), which permits unrestricted use, distribution, and reproduction in any medium, provided you give appropriate credit to the original author(s) and the source, provide a link to the Creative Commons license, and indicate if changes were made.

\section{References}

Bertness MD, Callaway R (1994) Positive interactions in communities. Trends Ecol Evol 9:187-191. https://doi.org/10.1016/01695347(94)90087-6

Beuchel F, Gulliksen B (2008) Temporal patterns of benthic community development in an Arctic fjord (Kongsfjorden, Svalbard): results of a 24-year manipulation study. Polar Biol 31:913-924. https://doi.org/10.1007/s00300-008-0429-9

Fetzer I, Lønne OJ, Pearson T (2002) The distribution of juvenile benthic invertebrates in an Arctic glacial fjord. Polar Biol 25:303315. https://doi.org/10.1007/s00300-001-0345-8

Feyling-Hanssen RW (1953) The barnacle balanus balanoides (Linne, 1766) in Spitsbergen. Brøggers boktrykkeris forlag, Oslo

Fredersdorf J, Møller R, Becker S, Wiencke C, Bischof K (2009) Interactive effects of radiation, temperature and salinity on different life history stages of the Arctic kelp Alaria esculenta (Phaeophyceae). Oecologia 160:483-492. https://doi.org/10.1007/s0044 2-009-1326-9

Glud RN (2008) Oxygen dynamics of marine sediments. Mar Biol Res 4:243-289. https://doi.org/10.1080/17451000801888726

Gutt J (2001) On the direct impact of ice on marine benthic communities, a review. Polar Biol 24:553-564. https://doi.org/10.1007/ s003000100262

Howat IM, Joughin I, Scambos TA (2007) Rapid changes in ice discharge from Greenland outlet glaciers. Science 315:1559-1561. https://doi.org/10.1126/science.1138478

Jarrett JN (1997) Temporal variation in substratum specificity of Semibalanus balanoides (Linnaeus) cyprids. J Exp Mar Biol Ecol 211:103-114. https://doi.org/10.1016/S0022-0981(96)02726-8

Jenkins SR, Norton TA, Hawkins SJ (1999) Settlement and postsettlement interactions between Semibalanus balanoides (L.) (Crustacea: Cirripedia) and three species of fucoid canopy algae. J Exp Mar Biol Ecol 236:49-67. https://doi.org/10.1016/S0022 -0981(98)00189-0

Khalaman VV, Komendantov AY, Malavenda SS, Mikhaylova TA (2016) Algae versus animals in early fouling communities of the White Sea. Mar Ecol Prog Ser 553:13-32. https://doi.org/10.3354/ meps 11767

Kjeldsen KK, Korsgaard NJ, Bjørk AA et al (2015) Spatial and temporal distribution of mass loss from the Greenland Ice Sheet since AD 1900. Nature 528:396-400. https://doi.org/10.1038/natur e16183

Krause-Jensen D, Duarte CM (2016) Substantial role of macroalgae in marine carbon sequestration. Nat Geosci 9:737-742. https://doi. org/10.1038/ngeo2790

Krause-Jensen D, Marbà N, Olesen B, Sejr MK, Christensen PB, Rodrigues J, Renaud PE, Balsby TJS, Rysgaard S (2012) Seasonal sea ice cover as principal driver of spatial and temporal variation in depth extension and annual production of kelp in
Greenland. Glob Chang Biol 18:2981-2994. https://doi.org/10. 1111/j.1365-2486.2012.02765.x

Lane DJW, Beaumont AR, Hunter JR (1985) Byssus drifting and the drifting threads of young post-larval mussel Mytilus edulis. Mar Biol 84:301-308

Lippert H, Iken K, Rachor E, Wiencke C (2001) Macrofauna associated with macroalgae in the Kongsfjord (Spitsbergen). Polar Biol 24:512-522. https://doi.org/10.1007/s003000100250

Meire L, Mortensen J, Meire P, Sejr MK, Rysgaard S, Nygaard R, Huybrechts P, Meysman FJR (2017) Marine-terminating glaciers sustain high productivity in Greenland fjords. Glob Chang Biol 23:5344-5357. https://doi.org/10.1111/gcb.13801

Mortensen J, Lennert K, Bendtsen J, Rysgaard S (2011) Heat sources for glacial melt in a sub-Arctic fjord (Godthåbsfjord) in contact with the Greenland Ice Sheet. J Geophys Res Ocean 116:1-13. https://doi.org/10.1029/2010JC006528

Mortensen J, Bendtsen J, Lennert K, Rysgaard S (2014) Seasonal variability of the circulation system in a west Greenland tidewater outlet glacier fjord, Godthåbsfjord $\left(64^{\circ} \mathrm{N}\right)$. J Geophys Res Earth Surf 119:2591-2603. https://doi.org/10.1002/2014JF003267

Murray C, Markager S, Stedmon CA, Juul-Pedersen T, Sejr MK, Bruhn A (2015) The influence of glacial melt water on bio-optical properties in two contrasting Greenlandic fjords. Estuar Coast Shelf Sci 163:72-83. https://doi.org/10.1016/j.ecss.2015.05.041

Nasrolahi A, Pansch C, Lenz M, Wahl M (2013) Temperature and salinity interactively impact early juvenile development: a bottleneck in barnacle ontogeny. Mar Biol 160:1109-1117. https:// doi.org/10.1007/s00227-012-2162-8

R Core Team (2017) A language and environment for statistical computing

Schiel DR, Foster MS (2006) The population biology of large brown seaweeds: ecological consequences of multiphase life histories in dynamic coastal environments. Annu Rev Ecol Evol Syst 37:343372. https://doi.org/10.1146/annurev.ecolsys.37.091305.110251

Thyrring J, Jensen KT, Sejr MK (2017) Gametogenesis of an intertidal population of Mytilus trossulus in NW Greenland: not a limitation for potential Arctic range expansion. Mar Ecol Prog Ser 574:6574. https://doi.org/10.3354/meps12179MARINE

Van As D, Andersen ML, Petersen D et al (2014) Increasing meltwater discharge from the Nuuk region of the Greenland ice sheet and implications for mass balance (1960-2012). J Glaciol 60:314-322. https://doi.org/10.3189/2014JoG13J065

Watson DI, Barnes DKA (2004) Temporal and spatial components of variability in benthic recruitment, a 5-year temperate example. Mar Biol 145:201-214. https://doi.org/10.1007/s0022 7-003-1291-5

Wiencke C, Clayton MN, Schoenwaelder M (2004) Sensitivity and acclimation to UV radiation of zoospores from five species of Laminariales from the Arctic. Mar Biol 145:31-39. https://doi. org/10.1007/s00227-004-1307-9

Woodson CB, McManus MA, Tyburczy JA et al (2012) Coastal fronts set recruitment and connectivity patterns across multiple taxa. Limnol Oceanogr 57:582-596. https://doi.org/10.4319/ lo.2012.57.2.0582

Yakovis EL, Artemieva AV, Fokin MV, Varfolomeeva MA, Shunatova NN (2013) Synchronous annual recruitment variation in barnacles and ascidians in the White Sea shallow subtidal 1999-2010. Hydrobiologia 706:69-79. https://doi.org/10.1007/s10750-012-1340-5 